\title{
Promotility Medications - Now and in the Future
}

\author{
G. Karamanolis J. Tack \\ Center for Gastroenterological Research, KU Leuven, Leuven, Belgium
}

\author{
Key Words \\ Gastric emptying • Colonic transit - Gastroparesis • \\ Functional dyspepsia - Constipation · Irritable bowel \\ syndrome · Gastric accommodation • \\ Antidopaminergic agents · Serotonergic agents • \\ Motilin receptor agonists
}

\begin{abstract}
Gastrointestinal promotility drugs stimulate smooth muscle contractions to enhance gastric emptying and small and large bowel transit. Currently available drug classes with prokinetic properties include antidopaminergic agents, serotonergic agents, and motilin-receptor agonists. Due to moderate prokinetic effects, poor symptomatic responses and the presence of adverse effects, there is a clear need for new classes of prokinetics. Several newer prokinetic drugs and drug classes are currently under evaluation. Selecting candidate agents and designing the appropriate therapeutic trials is hampered by the lack of insight in the pathophysiology of motilityrelated symptoms. As gastrointestinal motor disorders are chronic, relapsing, and remitting disorders, it seems desirable that studies with candidate prokinetic drugs establish a long-term efficacy and not only short-term effects on gastrointestinal functions.
\end{abstract}

\section{Introduction}

Gastrointestinal promotility drugs are used to stimulate, either directly or indirectly, smooth muscle contractions, leading to enhancement of gastric emptying and acceleration of small and large bowel transit. They are considered drugs of choice for the treatment of gastrointestinal functional motor disorders. Dopamine receptor antagonists, serotonergic agents acting as agonists at the 5- $\mathrm{TH}_{4}$ receptor and motilin receptor agonists are the drugs currently available on the market. Novel drugs include newer types of antidopaminergic and serotonergic agents, as well as new classes of prokinetics such as $\mathrm{CCK}_{\mathrm{A}}$ receptor antagonists and opioid receptor antagonists. The aim of the present article was to review and address the present use and efficacy of promotility drugs in the treatment of different gastrointestinal motor disorders, as well as the potential for future developments.

\section{Dopamine Receptor Antagonists}

The rationale for using antidopaminergic agents as prokinetics was based on observations that dopamine receptors are present in the gastrointestinal wall of several mammals, through which administration of dopamine causes potent inhibition of motility. Dopamine reduces lower esophageal sphincter (LES) tone, reduces gastric

\section{KARGER}

Fax +41613061234 E-Mail karger@karger.ch www.karger.com 
tone and impairs antroduodenal coordination [1-3]. These effects are partly due to activation of $\mathrm{D}_{2}$ dopamine receptors and the blockade of these inhibitory receptors by selective antagonists, such as domperidone and metoclopramide, have been suggested to result in a prokinetic effect [3-5]. Dopamine agonists are mostly used for the treatment of motility disorders of the upper gastrointestinal tract, such as functional dyspepsia and gastroparesis (idiopathic or secondary to other diseases).

\section{Domperidone}

Domperidone is a butyrophenone derivative that exerts antidopaminergic properties at peripheral $\mathrm{D}_{2}$ receptors $[3,6]$. The drug increases LES pressure and accelerates gastric emptying by inhibiting receptive fundic relaxation and enhancing gastroduodenal coordination. It is available in most countries of the world except for the USA. The main advantage of domperidone is that it does not cross the blood-brain barrier, and therefore extrapyramidal dystonic reactions are rare [4].

Domperidone has been studied primarily in patients with diabetic gastroparesis, in whom the drug accelerates both liquid and solid gastric emptying [7]. In controlled clinical trials, domperidone is more effective than placebo in patients with diabetic gastroparesis and in symptomatic diabetic patients with normal gastric emptying $[8,9]$. The prokinetic action of domperidone may be transitory in nature. Although its effect on solid gastric emptying was lost at 6 weeks [7, 9], persistent reduction in symptom severity has been reported [9]. Domperidone is the drug of choice for patients with Parkinson's disease with gastrointestinal symptoms secondary to gastroparesis or to dopaminergic drugs used to treat the disease [10].

For functional dyspepsia (FD), recent reviews suggest that domperidone is more effective than placebo, but the trials were often of poor quality with heterogeneity between studies [11-13]. The efficacy of domperidone was largely based on the global assessment of improvement by the investigator [11], and therefore further research to conclusively establish its place in FD therapy is needed [13]. In contrast to its action in the upper gut, domperidone has little prokinetic activity in the colon and may blunt the postprandial gastrocolonic response [14, 15].

The drug is given orally and the most common side effects relate to hyperprolactinemia, which may promote gynecomastia, galactorrhea, amenorrhea and impotence $[16,17]$. Hyperprolactinemia has been described in response to $\mathrm{D}_{2}$ receptor blockade by domperidone and seems to occur irrespective of the ability to the drug to cross the blood-brain barrier, as the pituitary is outside of this barrier. Hyperprolactinemia tends to decrease during the chronic administration of domperidone, and galactorrhea usually ceases within 1 week after discontinuation [16].

\section{Metoclopramide}

Metoclopramide, a substituted benzamide, is a major dopamine receptor antagonist that has been used as a prokinetic for at least 35 years. In addition to its action on $\mathrm{D}_{2}$ receptors, metoclopromide is known to interact with serotonergic receptors. Metoclopramide has moderate partial 5-hydroxytryptamine-4 $\left(5-\mathrm{HT}_{4}\right)$ receptor agonist properties and weak $5-\mathrm{HT}_{3}$ receptor antagonist properties [3]. It has been suggested that the activation of 5$\mathrm{HT}_{4}$ receptors by metoclopramide contributes to its gastrointestinal prokinetic action by enchancing acetylcholine (Ach) release from intrinsic cholinergic motor neurons [18]. The prokinetic properties of metoclopromide are limited to the proximal gut, where it increases esophageal, fundic, and antral contractile amplitudes, stimulates gastric emptying, and improves antropyloroduodenal coordination.

Metoclopramide is approved for use in diabetic gastroparesis and for prevention of postoperative and chemotherapy-induced nausea and vomiting. A recent review on gastroparesis suggests that metoclopramide provides symptomatic relief while accelerating gastric emptying in patients with idiopathic, diabetic, and postvagotomy gastroparesis [19]. Although its prokinetic effect may last for a short time period [20], diabetic patients with gastroparesis reported sustained symptom improvement on metoclopramide [21].

Metoclopramide most commonly is given orally, whereas intravenous administration is used for patients hospitalized with severe gastroparesis. The main limiting factor to the routine use of metoclopramide is its side effect profile. All prokinetics with central $\mathrm{D}_{2}$ receptor antagonist properties have been found to induce extrapyramidal reactions, and these effects may restrict the use of metoclopramide in up to $30 \%$ of patients. Side effects include drowsiness, agitation, irritability, fatigue, and dystonic reactions [16]. Prolonged treatment with metoclopramide can produce Parkinson-like symptoms [22], which subside within 2-3 months following discontinuation of drug. Metoclopramide-evoked dystonic reactions occur more frequently in women than men and in children and the elderly than in adults [23]. Antagonism of hypophyseal $\mathrm{D}_{2}$ receptors may result in increased prolactin release with subsequent development of breast engorgement, lactation, and menstrual irregularity. 


\section{Levosulpiride}

Levosulpiride is a benzamide derivative, which selectively inhibits $\mathrm{D}_{2}$ receptors and also interacts with $5-\mathrm{HT}_{4}$ receptors, and to a lesser extent with $5-\mathrm{HT}_{3}$ receptors [24, $25]$. It has been suggested that the serotonergic component possessed by levosulpiride may enhance its therapeutic efficacy in stimulating gastric and small bowel motility [25].

Indeed, a multicenter, double-blind, controlled study showed that levosulpiride was more effective than domperidone, metoclopramide, and placebo in patients with FD [26]. Moreover, levosulpiride was found to accelerate gastric emptying and improve gastrointestinal symptoms in patients with FD [27, 28], and in diabetic gastroparesis [29]. A recent randomized, double-masked study in patients with FD showed that levosulpiride is at least as effective as cisapride in the treatment of dysmotility-like FD [30]. Although chronic administration of levosulpiride reduced gastric sensitivity and decreased dyspeptic symptoms in patients with FD, it failed to modify gastric fundus compliance [31].

The drug is given orally and crosses the blood-brain barrier [24]. As a centrally acting antidopaminergic agent, levosulpiride associated with occurrence of extrapyramidal reactions and hyperprolactinemia.

\section{Others}

Itopride is a novel prokinetic agent that acts both as a dopamine $\mathrm{D}_{2}$ receptor antagonist and as an acetylcholinesterase inhibitor. The threshold of itopride to promote gastrointestinal motility is higher than that of cisapride, metoclopramide and domperidone [32]. Small clinical trials showed that therapy with itopride in patients with FD and GERD resulted in good symptomatic relief, and the drug was safe and well tolerated [33-35]. A recent large-scale clinical study confirmed that itopride was significantly better than placebo for symptom control in patients with FD [36]. The drug did not cause a QT prolongation and appears to be devoid of any cardiac side effects.

Clebopride and bromopride are two other antidopaminergic prokinetics which are less widely used and are marketed only in some countries [16]. Clebopride is the antidopaminergic drug that is most associated with the occurrence of dystonic reactions [16]. Chronic treatment with this compound may be associated with reversible Parkinson-like symptoms, but also with tardive dyskinesia, which is potentially irreversible.

Alizapride is a compound that has antagonistic properties at $\mathrm{D}_{2}$ receptors and is also considered as a prokinetic; however, it is almost exclusively used as an antiemetic drug [16].

\section{Serotonergic Agents}

Approximately $80 \%$ of total body $5-\mathrm{HT}$ is found in the gut where it plays a central role in the initiation of the peristaltic reflex on enteric neurons. Therefore, 5-HT receptors are among the primary targets for promotility drugs. The main effects relevant to gastrointestinal motility are mediated via $5-\mathrm{HT}_{3}, 5-\mathrm{HT}_{4}$ and $5-\mathrm{HT}_{1}$ receptors. $5-\mathrm{HT}_{4}$ receptor agonist induce peristaltic contraction by increasing release of Ach from excitatory neurons, whereas $5-\mathrm{HT}_{1}$ receptors are involved in the control of the accommodation reflex by releasing nitric oxide that relaxes the gastric fundus [37].

\section{Cisapride}

Cisapride was the first truly serotonergic drug used as prokinetic. It is a non-selective $5-\mathrm{HT}_{4}$ receptor agonist with partial weak $5-\mathrm{HT}_{3}$ antagonist effect [38]. The drug exhibits prokinetic actions in the distal esophagus, stomach, jejunum and colon and has reported efficacy for several gut functional or motor disorders.

The rationale for use of cisapride in GERD is based on its ability to increase the amplitude of esophageal contractions and the pressure of LES and to accelerate gastric emptying and orocecal transit $[37,39]$. In patients with FD, cisapride has been used in order to reverse abnormalities that are potentially involved in FD pathophysiology. Cisapride stimulates antral and duodenal contractions, improves antroduodenal coordination, and accelerates gastric emptying. In patients with gastroparesis, cisapride was shown to decrease symptoms, an effect that was reported to persist for up to 1 year [39-41]. In healthy volunteers, cisapride does not modify gastric compliance, but it enhances postprandial gastric relaxation [42]. These multiple actions may contribute to treatment efficacy of cisapride in FD, with a meta-analysis suggesting an overall positive, but modest, treatment effect [12]. In humans, cisapride stimulates small bowel motility [43] and decreases small bowel transit [44]. Based on studies in relatively small patient groups with this rare disorder, cisapride was reported to be effective in acute and chronic idiopathic pseudo-obstruction [45].

Cisapride has been withdrawn from most markets due to the occurrence of cardiac arrhythmias and sudden death. These effects were considered to be unrelated to the $5-\mathrm{HT}_{4}$ agonism but were to be due to the benzamide 
structure of cisapride, which blocks cardiac human etherà-go-go-related gene (HERG) potassium channels and can result in prolongation of QT interval $[19,46]$.

\section{Tegaserod}

Tegaserod, an aminoguanidine indole compound, is a partial $5-\mathrm{HT}_{4}$ receptor agonist which can also block 5- $\mathrm{HT}_{2 \mathrm{~b}}$ receptors [47]. Tegaserod has been shown to accelerate orocecal transit in healthy volunteers [48]. Tegaserod has mainly been evaluated for the treatment of constipation-predominant irritable bowel syndrome (IBS). In constipation-predominant IBS patients, tegaserod accelerates transit in the small intestine and ascending colon [49]. Moreover, clinical trials in constipation-predominant IBS have reported reductions in discomfort and improvement in constipation and bloating with tegaserod compared with placebo [50-52]. A recently published evidence-based position statement on the management of IBS assigned tegaserod a grade A recommendation based on the evidence available to support its use and its ability to provide global symptom relief [53]. The effective dose of tegaserod is $12 \mathrm{mg} /$ day in two divided doses (6 mg twice daily). The drug was significantly effective, with approximately a $10 \%$ advantage over placebo in the intent-to-treat population and up to $14 \%$ advantage over placebo in females and those with constipation during the baseline run-in period. Moreover, a large, prospective, multinational placebo-controlled study established that tegaserod was effective and well tolerated during both first and repeated treatment in women with constipation-predominant IBS [54].

Two recent multinational placebo-controlled randomized studies (one in Europe and another in North and South America) in patients with chronic constipation showed that tegaserod was also safe, well tolerated and effective in relieving symptoms of constipation $[55,56]$. Tegaserod also has a prominent prokinetic effect in the upper gut and the drug is currently under investigation for treatment of GERD, FD and gastroparesis. It has been shown to increase esophageal acid clearance [57], stimulate interdigestive small bowel motility and postprandial antral and intestinal motility [58], and accelerate gastric emptying in some [48] but not all studies of healthy volunteers [49]. In a preliminary report in patients with gastroparesis, tegaserod was shown to accelerate solid gastric emptying in a dose-dependent fashion [59]. A recent study, in healthy volunteers, showed that tegaserod enhanced gastric accommodation to a meal, indicating its potential for the treatment in FD patients with impaired accommodation [60]. Indeed, in FD patients with normal gastric emptying tegaserod significantly increased mealinduced gastric accommodation [61], and a phase $2 b$ study found positive effects on some dyspeptic symptoms (improvement in early satiety and postprandial fullness) [62].

Unlike cisapride, tegaserod has not been associated with cardiac dysrhythmic activity, was well tolerated and had no significant side effects $[60,63]$. The most frequent adverse effects were gastrointestinal related, such as diarrhea and abdominal pain, both of them mild $[55,56,60$, 63].

\section{Renzapride}

Renzapride is a novel substituted benzamide that possesses both 5- $\mathrm{HT}_{4}$ receptor full agonist [64] and 5- $\mathrm{HT}_{3}$ receptor antagonist properties $[64,65]$. Although these properties are similar to those of cisapride, renzapride was 10-fold less potent than cisapride in blocking HERG potassium channels that are responsible for causing cardiac arrhythmias [66].

Renzapride was found to cause significant dose-related acceleration of colonic transit time, particularly ascending colonic emptying, in patients with constipation-predominant IBS [67]. Moreover, preliminary studies showed that renzapride may improve symptoms in patients who are constipation-predominant $[68,69]$.

In order to assess the safety and efficacy of renzapride in patients with constipation-predominant IBS, a placebo-controlled study was designed [70]. This study showed that renzapride had a prokinetic effect, as demonstrated by the increases in overall gastrointestinal motility, and that this effect appeared to be dose-dependent. Moreover, renzapride was well tolerated with lack of effect on cardiovascular function and on prolactin levels. The most common treatment adverse events were abdominal pain, headache, constipation and diarrhea (reported only in during renzapride treatment).

In addition to treating constipation, renzapride also accelerated gastric emptying in healthy volunteers and in a small group of diabetic patients with gastroparesis and it may thus be useful in treating gastroparetic patients [71, 72].

\section{Other 5- $\mathrm{HT}_{4}$ Receptor Agonists}

Second-generation 5- $\mathrm{HT}_{4}$ receptor agonists devoid of side effects on cardiac depolarization are currently under investigation as an alternative to cisapride.

Mosapride is a benzaminide derivative that exhibits both 5- $\mathrm{HT}_{4}$ receptor agonist and 5- $\mathrm{HT}_{3}$ receptor antagonist properties and is commercially available in Japan. 
Mosapride produced no side effects on the HERG current and should be a safe alternative to cisapride [66]. Mosapride has been proposed for use in upper gut motility disorders and it was shown to alleviate GERD [73] and to have significant effect, comparable to those of cisapride on acid reflux parameters and esophageal motor function in patients with GERD [74]. However, a study in patients with FD showed no benefit of mosapride over placebo [75].

Prucalopride belongs to a new class of drugs known as benzofurancarboxamide and is a highly selective $5-\mathrm{HT}_{4}$ receptor agonist. Prucalopride has been shown to improve stool frequency and consistency and to decrease gut transit time in healthy volunteers $[76,77]$. In clinical trials it has been used for treatment of chronic constipation with promising results [78-80]. The drug was shown to decrease total gut transit and to normalize stool consistency in patients with resistant constipation. Prucalopride was generally well tolerated, with mild to moderate in severity side effects. The commonest adverse effects were headache, nausea and abdominal cramps and there were no clinically relevant effects on cardiovascular parameters [78-80]. Clinical trials have been discontinued because of carcinogenicity in animals [17].

\section{5-HT $T_{1}$ Receptor Agonists}

$5-\mathrm{HT}_{1}$ receptors can mediate enhanced postprandial relaxation and it would be logical to try $5-\mathrm{HT}_{1}$ receptor agonists in FD. Administration of sumatriptan, a 5-HT receptor agonist used in the treatment of migraine, relaxes the proximal stomach in healthy subjects [81]. In acute studies, subcutaneous administration of sumatriptan was shown to restore the meal-induced relaxation in patients with impaired gastric accommodation and to increase the amount of calories ingested at maximum satiety in patients with early satiety [82]. Due to its pharmacological properties, its cost, and its mode of administration, subcutaneous sumatriptan is not suitable for chronic treatment of FD. A nasal spray formulation of sumatriptan had no significant effect on proximal stomach function [83].

Buspirone is a non-selective 5- $\mathrm{HT}_{1}$ receptor agonist, used in the treatment of panic attacks. In a placebo-controlled study in patients with FD, we confirmed that buspirone was superior to placebo in alleviating dyspeptic symptoms, and that this was associated with an enhancement of the accommodation to a meal [84].

Short-term studies in healthy volunteers using the novel 5- $\mathrm{HT}_{1}$ receptor agonist R-137696 established that the drug had a dose-dependent relaxatory effect on the prox- imal stomach [85]. A subsequent 4-week multicenter placebo-controlled study failed to show any effect of the drug on gastric compliance and accommodation, suggesting that desensitization to the drug effect had occurred [86].

\section{Motilin Receptor Agonists}

Motilin is an endogenous peptide that is cyclically released during the interdigestive state, where it has been implicated in the initiation of phase III contractile activity of the migrating motor complex [87]. Motilin stimulates motility through its action at gut receptors; there is a gradient of motilin receptors from stomach to terminal ileum, with the highest density in the upper gut [88]. Agonists of motilin receptors, such as erythromycin and structurally related synthetic analogues devoid of antibacterial properties (motilides), are potent prokinetics with clinical efficacy in motility disorders [89].

\section{Erythromycin}

Erythromycin, a macrolide antibiotic, stimulates gut motility through a direct action at motilin receptors on smooth muscle and on enteric nerves [88-90]. Erythromycin affects the motor behavior of different gastrointestinal regions. The drug increased LES pressure by stimulation of cholinergic nerves [91]; however, in reflux disease, no significant differences in acid exposure times were observed between placebo and erythromycin [92].

Several short-term studies reported that erythromycin could stimulate gastric emptying in patients with diabetic, idiopathic, and postvagotomy gastroparesis [93-95]. Erythromycin is more potent when used intravenously, whereas orally erythromycin appears to be less effective $[94,96]$. A recent meta-analysis of prokinetics used in gastroparesis reported that the effects of erythromycin on gastric emptying are greater than observed with other prokinetic drugs [13]. Regarding the treatment of symptoms in gastroparetic patients on oral erythromycin, a recent review showed that improvement was noted in only half of the patients [97]. A desensitization of the motilin receptor when using oral erythromycin in high doses for long period was suggested as a possible explanation [98]. However, we recently showed that in a setting where desensitization played no role (acute administration of erythromycin), erythromycin-enhanced gastric emptying was not associated with a beneficial effect on meal-related symptom severity in patients with FD and delayed gastric emptying [99]. These findings suggest that the therapeutic 
effect of erythromycin in the treatment of FD patients with delayed gastric emptying is at best modest.

Furthermore, studies assessing the effect of erythromycin on gastric tone reported that administration of motilin or of erythromycin reduced meal-induced relaxation [100-102], thereby enhancing sensitivity to gastric distention [103]. This adverse effect of erythromycin on gastric accommodation to a meal may contribute to its overall poor symptomatic response in patients with FD. Therefore, the effect of the drug on the proximal stomach should be considered when erythromycin is used in FD patients, since it seems to be inappropriate in patients with impaired accommodation. It is important to note that the effect of erythromycin on the human fundus is a direct smooth muscle effect [100] while the effect on the antrum is neurally mediated [90]. Both effects may contribute to acceleration of gastric emptying, but the effect on the fundus may affect accommodation, sensitivity, and dyspeptic symptoms.

The effect of erythromycin on colonic transit is controversial. In healthy volunteers, erythromycin was found to reduce or not to affect the transit time of radiopaque markers in the proximal and distal colon, respectively $[104,105]$. The possible prokinetic effect of erythromycin on colon was not observed in patients with IBS [106], an observation that is not surprising in view of the gradient of motilin receptors along the gut.

\section{ABT-229 (Alemcinal)}

ABT-229 is a novel motilin receptor agonist devoid of the antibacterial activity [107] that has been studied in clinical trials of FD and of GERD. This agent was 101,000 times more potent as prokinetic than erythromycin $[107,108]$. It has been shown that ABT-229 accelerates gastric emptying in a dose-dependent way in healthy subjects [109]. However, the outcomes of clinical trials with ABT-229 were unequivocally disappointing with regard to symptom improvement, both in FD patients with and without delayed emptying [110]. In fact, patients receiving ABT-229 appeared to have a worse outcome. Similarly, administration of ABT-229 in patients with diabetic gastroparesis had an adverse effect and increased the severity of dyspeptic symptoms [111]. The negative outcomes of these studies may be explained by occurrence of tachyphylaxis $[98,109]$ or by the fact that motilide prokinetics have an adverse effect on gastric accommodation to a meal [100-103]. Thus, when selecting prokinetic drugs for clinical application, the issue of tachyphylaxis as well as effects on the proximal stomach should be considered [89].
Recent clinical studies assessed the effect of ABT-229 on acid reflux in patients with GERD, showing that the drug neither affected esophageal motility nor accelerated gastric emptying [112-114]. In one study, ABT-229 was able to slightly reduce the esophageal acid exposure over $24 \mathrm{~h}$ [114], while the other study failed to report any significant effect of ABT-229 on esophageal acid exposure $[112,113]$.

\section{Other Motilin Receptor Agonists}

$K C 11458$ is a non-peptide motilin agonist that has a macrolide structure derived from erythromycin. KC 11548 does not possess antibiotic properties, its affinity for the motilin receptor is 10 -fold higher than erythromycin and it has been shown to accelerate gastric emptying in healthy subjects $[115,116]$. However, a recent clinical study evaluating the acute effects of KC 11548 on gastric emptying in patients with diabetic gastroparesis showed that the drug failed to improve emptying of either solid or liquid and did not improve symptoms when compared with placebo [117].

GM 611 (mitemcinal) is an erythromycin derivative that acts as an agonist at the motilin receptor [118]. It is being developed as a potential treatment for reflux esophagitis, non-ulcer dyspepsia and diabetic gastroparesis. GM-611 stimulates and promotes peristalsis in the stomach and other segments of the gastrointestinal tract [118]. Besides being a motilin agonist, GM-611 was shown to produce a dose-dependent sustained depolarization of rabbit duodenal smooth muscle. Depolarization appeared to be associated with activation of monovalent cation-selective channels [118].

\section{Cholecystokinin-1 (CCK-1) Receptor Antagonists}

Cholecystokinin (CCK) is a neuropeptide released from duodenal endocrine cells in response to a variety of nutrients, notably lipids and fatty acids, and circulating CCK inhibits gastric emptying [119]. The gastrointestinal effects of CCK are mediated by CCK-1 receptors that are localized in gut tract smooth muscles and vagal afferents $[120,121]$. The role of CCK-1 receptors in regulating gut motility makes these receptors important targets for drugs that could stimulate gastric motility.

Loxiglumide is a CCK-1 receptor antagonist that blocks the inhibitory effects of a lipid meal on gastric motility and gastric emptying. In a magnetic resonance imaging study of gastric emptying in healthy volunteers, 
loxiglumide stimulated antral contractions and accelerated gastric emptying [122]. Furthermore, loxiglumide was able to block the inhibitory effect of intraduodenal infusion of lipid on gastric tone and compliance in a gastric barostat study [123].

Dexloxiglumide, the R-isomer of loxiglumide, has enhanced potency and selectivity for CCK-1 receptors [121]. The drug blocks CCK-1 receptors localized to gastric vagal terminals and it reverses lipid-induced delayed gastric emptying in healthy subjects [124]. In FD patients, dexloxiglumide compared to placebo decreased gastric compliance and inhibited gastric accommodation to a meal, but it also reduced dyspeptic symptoms [125]. Dexloxiglumide has also been tested in patients with constipation-predominant IBS. A phase II trial has shown that in constipated female IBS patients, dexloxiglumide significantly improved abdominal pain and discomfort compared to placebo [126]. However, a recent study evaluating the pharmacodynamic effects of dexloxiglumide on gastrointestinal transit in IBS patients failed to show a significant improvement in treating symptoms [127]. Dexloxiglumide was associated with accelerated gastric emptying, and delayed ascending colon emptying, with no significant effect on overall colonic transit in constipated IBS patients.

\section{$\mu$-Opioid Receptor Antagonists}

Opiates and opioids inhibit propulsive motility and cause constipation in healthy subjects [128]. The constipating actions of $\mu$-opioid agonists are mediated by a peripheral action in the enteric nervous system, while their analgesic effects are mediated predominately by the central nervous action [121, 129, 130]. Thus, peripherally acting $\mu$-opioid antagonist may be able to preserve normal gut motility while producing analgesic effects.

Alvimopan is an orally-active, peripherally-restricted $\mu$-opioid antagonist that has promising prokinetic properties [131]. In a phase II study, the drug was shown to have dose-related efficacy in the treatment of opiate bowel dysfunction [132]. Alvimopan also accelerated the time to first bowel movement in patients with chronic pain receiving opiates without inhibition of the pain-relieving effect of the opiate [130]. Alvimopan has been tested in two studies of patients undergoing abdominal surgery $[133,134]$. In these studies, alvimopan accelerated recovery of gastrointestinal function, shortened the time to hospital discharge, and was well tolerated. In healthy subjects, alvimopan accelerated colonic transit [135], and this acceleration was confirmed in patients with chronic constipation [136].

\section{Miscellaneous Prokinetic Drugs}

Several other medications with prokinetic properties have been proposed for use in different gut motor disorders.

Z-338 (acotiamide) is a novel compound with gastroprokinetic properties, based on a mechanism of action that differs from other gastroprokinetic agents. Z-338 exerts its activity via antagonism of the inhibitory muscarinic type 1 and type 2 (M1/M2) autoreceptors. A recent phase IIa, randomized, double-blind, placebo-controlled study showed that the drug provided significantly better overall symptom relief in patients with FD, although the mechanism underlying this improvement was not shown to be related to enhancement of gastric emptying, or to decreased gastric sensitivity. The drug may have the potential to enhance impaired accommodation [137].

Leuprolide is a gonadotropin-releasing hormone analogue that has been shown to decrease symptom severity in patients with functional bowel disorders, inducing propagative gastric and small intestinal motor activity [138]. As leuprolide induced amenorrhea and might lead to osteoporosis, its use in functional disorders should be considered carefully [17].

Ghrelin is a 28-amino-acid motilin-related peptide that was first derived from rat stomach [139]. Ghrelin is the natural ligand for the growth hormone secretagogue receptor, and animal studies revealed that it has distinct effects on gastrointestinal motility [140, 141]. Recently, we confirmed a strong stimulatory effect of ghrelin on gastric interdigestive motility in man [142]. Moreover, we have shown that acute administration of ghrelin in patients with idiopathic gastroparesis enhanced gastric emptying and improved meal-induced symptoms [143].

Gastric relaxation is partly mediated via a vagovagal reflex pathway that activates intrinsic non-adrenergic, non-cholinergic neurons [144], using nitric oxide (NO) as neurotransmitter [145]. Gastric tone is also modulated by the sympathetic nervous system [146]. Thus, drugs that modulate these pathways, such as NO donors and $\alpha$-adrenoceptors, may provide tools to pharmacologically alter postprandial gastric relaxation. Acute studies in patients with FD have shown some benefit of glycerin nitrate [147]. The drug improved proximal stomach accommodation to a meal and alleviated dyspeptic symptoms, but prolonged use is generally associated with undesirable 
vascular side effects due to the lack of specificity. Sildenafil blocks phosphodiesterase type 5, which degrades NOstimulated $3^{\prime}, 5^{\prime}$-cyclic monophosphate (cGMP), thereby relaxing smooth muscle in various organs. Acute pretreatment with sildenafil also relaxed the proximal stomach [148] and trials evaluating phosphodiesterase inhibitors in FD seem warranted. Clonidine, an $\alpha_{2}$-receptor agonist, increased gastric compliance, relaxed the stomach, and reduced gastric sensation in healthy subjects [149]. Acute administration of clonidine was found to decrease mealinduced symptoms in FD [150]. Reports about the effects of clonidine on gastric emptying are inconclusive. In healthy volunteers, clonidine had no significant effect on gastric emptying time [149, 151], whereas in patients with diabetic gastroparesis, clonidine treatment was associated with acceleration of gastric emptying [152].

\section{Conclusion}

Currently available agents for treatment of gastrointestinal motor disorders include several major classes, such as antidopaminergic agents, serotonergic agents, and motilin-receptor agonists. Due to moderate prokinetic effects, poor symptomatic responses and the presence of adverse effects, there is a clear need for new classes of prokinetics. Several other prokinetic drugs, with mixed or novel pharmacological profiles, are under development or under investigation. However, the lack of insight into the pathophysiology of motor disorders creates major difficulties in selecting candidate therapeutic agents and in designing appropriate studies to investigate their therapeutic potential. Moreover, the pathophysiological heterogeneity of gastrointestinal functional disorders undoubtedly has a negative impact on the use of a single drug class for treating subsets of patients with different underlying pathophysiological abnormalities. Therefore, large-scale comparative clinical trials for both old and new classes of prokinetics are awaited in order to assess their dose, efficacy and safety. As gastrointestinal motor disorders are chronic, relapsing, and remitting disorders, it seems desirable that studies with candidate prokinetic drugs establish a longterm efficacy and not only short-term effects on gastrointestinal functions.

\section{References}

-1 Orloff LA, Orloff MS, Bunnett NW, Walsh JH: Dopamine and norepinephrine in the alimentary tract changes after chemical sympathectomy and surgical vagotomy. Life Sci 1985;36: 1625-1631.

>2 Demol P, Ruoff HJ, Weihrauch TR: Rational pharmacotherapy of gastrointestinal motility disorders. Eur J Pediatr 1989; 148:489-495.

$\checkmark 3$ Tonini M: Recent advances in the pharmacology of gastrointestinal prokinetics. Pharmacol Res 1996;33:217-226.

$\checkmark 4$ Brogden RN, Carmine AA, Heel RC, Speight TM, Avery GS: Domperidone. A review of its pharmacological activity, pharmacokinetics and therapeutic efficacy in the symptomatic treatment of chronic dyspepsia and as an antiemetic. Drugs 1982;24:360-400.

5 Pinder RM, Brogden RN, Sawyer PR, Speight TM, Avery GS: Metoclopramide: a review of its pharmacological properties and clinical use. Drugs 1976;12:81-131.

$\checkmark 6$ MacDonald TM: Metoclopramide, domperidone and dopamine in man: actions and interactions. Eur J Clin Pharmacol 1991;40:225230.

7 Horowitz M, Harding PE, Chattertin BE, Collins PJ, Shearman DJC: Acute and chronic effect of domperidone on gastric emptying in diabetic autonomic neuropathy. Dig Dis Sci 1985;30:1-9.
8 Patterson D, Abell T, Rothstein R, Koch K, Barnett J: A double-blind multicenter comparison of domperidone and metoclopramide in the treatment of diabetic patients with symptoms of gastroparesis. Am J Gastroenterol 1999; $94: 1230-1234$.

$>9$ Davis RH, Clench MH, Mathias JR: Effects of domperidone in patients with chronic unexplained upper gastrointestinal symptoms: a double-blind, placebo-controlled study. Dig Dis Sci 1988;33:1505-1511.

10 Soykan I, Sarosiek I, McCallum RW: The effect of chronic oral domperidone therapy on gastrointestinal symptoms, gastric emptying, and quality of life in patients with gastroparesis. Am J Gastroenterol 1997;92:976-980.

11 Veldhuyzen van Zanten SJ, Jones MJ, Verlinden M, Talley NJ: Efficacy of cisapride and domperidone in functional dyspepsia: a metaanalysis. Am J Gastroenterol 2001;96:689696.

12 Finney JS, Kinnersley N, Hughes M, O’ BryanTear CG, Lothian J: Meta-analysis of antisecretory and gastrokinetic compounds in functional dyspepsia. J Clin Gastroenterol 1998; 26:312-320.

13 Sturm A, Holtmann G, Goebell H, Gerken G: Prokinetics in patients with gastroparesis: a systematic analysis. Digestion 1999;60:422427.
4 Wiley J, Owyang C: Dopaminergic modulation of rectosigmoid motility: action of domperidone. J Pharmacol Exp Ther 1987;242:548551.

15 Milo R: Use of peripheral dopamine antagonist, domperidone, in the management of gastrointestinal symptoms in patients with irritable bowel syndrome. Curr Med Res Opin 1980; 6:577-584

$\checkmark 16$ Tonini M, Cipollina L, Poluzzi E, Cremas F, Corazza GR, De Ponti F: Clinical implications of enteric and central $\mathrm{D}_{2}$ receptor blockade by antidopaminergic gastrointestinal prokinetics. Aliment Pharmacol Ther 2004; 19:379-390.

17 Hasler WL: Pharmacotherapy for intestinal motor and sensory disorders. Gastroenterol Clin North Am 2003;32:707-732.

18 Briejer MR, Akkermans LM, Schuurkes JA: Gastrointestinal prokinetic benzamides: the pharmacology underlying stimulation of motility. Pharmacol Rev 1995;47:631-651.

19 American Gastroenterology Association: Technical review on the diagnosis and treatment of gastroparesis. Gastroenterology 2004; 127:1592-622.

20 Longstreth GF, Malagelada JR, Kelly KA: Metoclopramide stimulation of gastric motility and emptying in diabetic gastroparesis. Ann Intern Med 1977;86:195-196. 
-21 Lata PF, Pigarelli DL: Chronic metoclopramide therapy for diabetic gastroparesis. Ann Pharmacother 2003;37:122-126.

-22 Ganzini L, Casey DE, Hoffman WF, McCall AL: The prevalence of metoclopramide-induced tardive dyskinesia and acute extrapyramidal movement disorders. Arch Intern Med 1993;153:1469-1475.

-23 Miller LG, Jankovic J: Metoclopramide-induced movement disorders. Clinical findings with a review of the literature. Arch Intern Med 1989; 149:2486-2492.

-24 Rossi F, Forgione A: Pharmatoxicological aspects of levosulpiride. Pharmacol Res 1995;31: 81-94.

-25 Tonini M, De Giorgio R, Spelta V, et al: 5-HT receptors contribute to the motor stimulating effect of levosulpiride in the guinea-pig gastrointestinal tract. Dis Liver Dis 2003;35:244250.

26 Corraza GR, Biagi F, Albano O, et al: Levosulpiride in functional dyspepsia: a multicentric double-blind, controlled trial. Ital J Gastroenterol 1996;28:317-323.

-27 Arienti V, Corazza GR, Sorge M, et al: The effects of levosulpiride on gastric and gall-bladder emptying in functional dyspepsia. Aliment Pharmacol Ther 1994;8:631-638.

28 Mansi C, Borro P, Giacomini M, et al: Comparative effects of levosulpiride and cisapride on gastric emptying and symptoms in patients with functional dyspepsia and gastroparesis. Aliment Pharmacol Ther 2000;14:561-569.

29 Mansi C, Savarino V, Vigneri S, et al: Gastrokinetic effects of levosulpiride in dyspeptic patients with diabetic gastroparesis. Am J Gastroenterol 1995;11:1989-1993.

30 Mearin F, Rodrigo L, Perez-Mota A, et al: Levosulpiride and cisapride in the treatment of dysmotility-like functional dyspepsia: a randomized, double-masked trial. Clin Gastroenterol Hepatol 2004;2:301-308.

-31 Distrutti E, Fiorucci S, Hauer SK, et al: Effect of acute and chronic levosulpiride administration on gastric tone and perception in functional dyspepsia. Aliment Pharmacol Ther 2002; 16:613-622

- 32 Iwanaga Y, Miyashita N, Morikawa K, et al: A novel water-soluble dopamine-2 antagonist with anticholinesterase activity in gastrointestinal motor activity. Comparison with domperidone and neostigmine. Gastroenterology 1990;99:401-408

-33 Kim YS, Kim TH, Chi CS, et al: Effect of itopride, a new prokinetic, in patients with mild GERD: a pilot study. World J Gastroenterol 2005;11:4210-4214.

- 34 Amarapurkar DN, Rane P: Randomised, double-blind, comparative study to evaluate the efficacy and safety of ganaton (itopride hydrochloride) and mosapride citrate in the management of functional dyspepsia. J Indian Med Assoc 2004; 102:735-737.

-35 Sawant P, Das HS, Desai N, et al: Comparative evaluation of the efficacy and tolerability of itopride hydrochloride and domperidone in patients with non-ulcer dyspepsia. J Assoc Physicians India 2004;52:626-628.
36 Holtmann G, Schmittker J, Boos G, et al: A randomized, double-blind, placebo-controlled dose-finding study of itopride for the treatment of patients with functional dyspepsia (abstract). Gastroenterology 2004;126:A100.

37 Spiller R: Serotonergic modulating drugs for functional gastrointestinal disease. $\mathrm{Br} \mathrm{J}$ Clin Pharmacol 2002;54:11-20.

38 Cooke HJ, Harvey HV: The effects of cisapride on serotonin-evoked mucosal response in guinea pig ileum. Eur J Pharmacol 1984;98:147-148.

39 De Ponti F, Malagelada JR: Drug treatment of functional gut disorders. Pharmacol Ther 1998; 80:49-88.

-40 Frases RJ, Horowitz M, Maddox AF, Dent J: Postprandial antropyloroduodenal motility and gastric emptying in gastroparesis - effects of cisapride. Gut 1994:35:172-178.

41 Braden B, Enghofer M, Schaub M, et al: Longterm cisapride treatment improves diabetic gastroparesis but not glycaemic control. Aliment Pharmacol Ther 2002;16:1341-1346.

42 Tack J, Broeckaert D, Coulie B, Janssens J: The influence of cisapride on gastric tone and the perception of gastric distension. Aliment Pharmacol Ther 1998;12:761-766.

43 Coremans G, Janssens J, Vantrappen G, et al: Cisapride stimulates propulsive motility patterns in human jejunum. Dig Dis Sci 1988;33: 1512-1519.

44 Madsen JL: Effects of cisapride on gastrointestinal transit in healthy humans. Dig Dis Sci 1990;35:1500-1504.

45 Wiseman LR, Faulds D: Cisapride. An update review of its pharmacology and therapeutic efficacy as a prokinetic agent in gastrointestinal motility disorders. Drugs 1994;47:116-152.

46 Tonini M, De Ponti F, Di Nucci A, et al: Review article: cardiac adverse effects of gastrointestinal prokinetics. Aliment Pharmacol Ther 1999; 13:1585-1591.

47 Beattie DT, Smith JA, Marquess D, et al: The $5-\mathrm{HT}_{4}$ receptor agonist, tegaserod, is a potent $5-\mathrm{HT}_{2 \mathrm{~b}}$ receptor antagonist in vitro and in vivo. Br J Pharmacol 2004;143:549-560.

48 Degan L, Matzinger D, Merz M, et al: Tegaserod, a 5- $\mathrm{HT}_{4}$ receptor partial agonist, accelerates gastric emptying and gastrointestinal transit in healthy male subjects. Aliment Pharmacol Ther 2001;15:1745-1751.

49 Prather CM, Camilleri M, Zinsmeister AR, et al: Tegaserod accelerates orocecal transit in patients with constipation-predominant irritable bowel syndrome. Gastroenterology 2000;118: 463-468.

50 Kellow J, Lee OY, Chang FY, Thongsawat S, Mazlam MZ, Yuen H, Gwee KA, Bak YT, Jones J, Wagner A: An Asia-Pacific, doubleblind, placebo-controlled, randomised study to evaluate the efficacy, safety and tolerability of tegaserod in patients with irritable bowel syndrome. Gut 2003;52:671-676.

51 Muller-Lissner SA, Fumagali I, Bardhan KD, et al: Tegaserod, a 5- $\mathrm{HT}_{4}$ receptor partial agonist, relieves symptoms in irritable bowel syndrome patients with abdominal pain, bloating and constipation. Aliment Pharmacol Ther 2001;15:1655-1666.
52 Novick J, Miner P, Krause R, et al: A randomized, double-blind, placebo-controlled trial of tegaserod in female patients suffering from irritable bowel syndrome with constipation. Aliment Pharmacol Ther 2002;16:1877-1888.

53 American College of Gastroenterology Functional Gastrointestinal Disorders Task Force: Evidence-based position statement on the management of irritable bowel syndrome in North America. Am J Gastronterol 2002; 97(suppl 2):S1-S5.

-54 Tack J, Muller-Lissner S, Bytzer P, et al: A randomised controlled trial assessing the efficacy and safety of repeated tegaserod therapy in women with irritable bowel syndrome with constipation. Gut 2005;54:1707-1713

55 Kamm MA, Muller-Lissner S, Talley NJ, et al: Tegaserod for the treatment of chronic constipation: a randomized, double-blind, placebocontrolled multinational study. Am J Gastroenterol 2005; 100:362-372.

56 Johanson JF, Wald A, Tougas G, et al: Tegaserod is effective and well tolerated in chronic constipation: findings from a randomized, double-blind, placebo-controlled trial (abstract). Gastroenterology 2004;124:A64.

57 Karhilas PJ, Quigley EM, Castell DO, Spechler TJ: The effects of tegaserod (HTF 919) on oesophageal acid exposure in gastro-oesophageal reflux disease. Aliment Pharmacol Ther 2000; 14:503-509.

58 Di Stefano M, Vos R, Janssens J, Tack JF: Effect of tegaserod, a $5-\mathrm{HT}_{4}$ receptor partial agonist, on interdigestive and postprandial gastrointestinal motility in healthy volunteers (abstract). Gastroenterology 2003;124:A163.

59 Tougas G, Chen Y, Luo D, et al: Tegaserod improves gastric emptying in patients with gastroparesis and dyspeptic symptoms (abstract). Gastroenterology 2003;124:A54.

60 Tack J, Vos R, Janssens J, et al: Influence of tegaserod on proximal gastric tone and on the perception of gastric distension. Aliment Pharmacol Ther 2003; 18:1031-1037.

61 Tack J, Vos R, Bisschops R, et al: Influence of tegaserod, a partial 5- $\mathrm{HT}_{4}$ receptor agonist, on sensory and motor function of proximal stomach in functional dyspepsia. Gastroenterology 2005;128(4):A94-A95.

62 Tack J, Delia T, Ligozio G, et al: A phase II trial with tegaserod in functional dyspepsia patients with normal gastric emptying (abstract). Gastroenterology 2002;120:A20.

-63 Fidelholtz J, Smith W, Rawls J, et al: Safety and tolerability of tegaserod in patients with irritable bowel disease and diarrhea symptoms. Am J Gastroenterol 2002;97:11761181.

64 Dumuis A, Sebben M, Bockaert J: BRL 24924: a potent agonist at a non-classical 5-HT receptor positively coupled with adenylate cyclase in colliculi neurons. Eur J Pharmacol 1989;162: 381-384.

65 Briejer MR, Akkermans LMA, Schuurkes JAJ: Gastrointestinal prokinetic benzamides: the pharmacology underlying stimulation of motility. Pharmacol Rev 1995;47:631-651. 
-66 Potet F, Bouyssou T, Escande D, Baro I: Gastrointestinal prokinetic drugs have different affinity for the human cardiac human ether-àgogo $\mathrm{K}^{+}$channel. J Pharmacol Exp Ther 2001; 299:1007-1012.

-67 Camilleri M, McKinzie S, Fox J, Foxx-Orenstein A, Burton D, Thomforde G, et al: A randomized, controlled trial of renzapride on colonic motility in patients with constipation-predominant irritable bowel syndrome. Clin Gastroenterol Hepatol 2004;2:895-904.

68 Meyers NL, Palmer RMJ, George A: Efficacy and safety of renzapride in patients with constipation-predominant IBS: a phase IIb study in the UK Primary Healthcare Setting. Gastroenterology 2004; 126:A640.

69 Henderson JC, Palmer RMJ, Meyers NL, Spiller RC: A phase Iib clinical study of renzapride in mixed-symptom (alternating) irritable bowel syndrome. Gastroenterology 2004;126: A644.

70 Tack J, Middleton SJ, Horne MC, Piessevaux H, Bloor JS, Meyers NL, Palmer RMJ: Pilot study of the efficacy of renzapride on gastrointestinal motility and symptoms in patients with constipation-predominant irritable bowel syndrome (submitted).

71 Meyers NL, Palmer RMJ, Wray HA, Bloor JR, Wilding IR: Effects of single oral doses of renzapride on gastrointestinal motility in fasted, healthy subjects (abstract). Gut 2002;51(suppl III):A137.

72 Mackie AD, Ferrington C, Cowan S, et al: The effects of renzapride, a novel prokinetic agent, in diabetic gastroparesis. Aliment Pharmacol Ther 1991;5:135-142.

73 Kanaizumi T, Nakano N, Matsui Y, et al: Prokinetic effect of AS-4370 on gastric emptying in healthy adults. Eur J Clin Pharmacol 1991; 29:670-675.

74 Ruth M, Finizia C, Cange L, Lundell L: The effect of mosapride on esophageal motor function and acid reflux in patients with gastroesophageal reflux disease. Eur J Gastroenterol Hepatol 2003; 15:1115-1121.

-75 Hallerback BI, Bommelaer G, Bredberg E, et al: Dose finding study of mosapride in functional dyspepsia: a placebo-controlled, randomized study. Aliment Pharmacol Ther 2002;16:959-967.

76 Poen AC, Felt-Bersma RJ, Van Dongen PA, Meuwissen SG: Effect of prucalopride, a new enterokinetic agent, on gastrointestinal transit and anorectal function in healthy volunteers. Aliment Pharmacol Ther 1999;13:14931497.

77 Bouras EP, Camilleri M, Burton DD, McKinzie S: Selective stimulation of colonic transit by the benzofuran $5-\mathrm{HT}_{4}$ agonist, prucalopride, in healthy humans. Gut 1999;44:682686.

78 Bouras EP, Camilleri M, Burton DD, et al: Prucalopride accelerates gastrointestinal and colonic transit in patients with constipation without a rectal evacuation disorder. Gastroenterology 2001;120:354-360.
Emmanuel AV, Roy AJ, Nicholls TJ, Kamm MA: Prucalopride, a systemic enterokinetic, for the treatment of constipation. Aliment Pharmacol Ther 2002;16:1347-1356.

-80 Coremans G, Kerstens R, De Pauw M, Stevens $\mathrm{M}$ : Prucalopride is effective in patients with severe chronic constipation in whom laxatives fails to provide adequate relief. Results of a double-blind, placebo-controlled clinical trial. Digestion 2003;67:82-89.

81 Tack J, Coulie B, Wilmer A, Andrioli A, Janssens J: Effect of sumatriptan on gastric fundus tone and on the perception of gastric distension in man. Gut 2000;46:468-473.

82 Tack J, Piessevaux H, Coulie B, Caenepeel P, Janssens J: Role of impaired gastric accommodation to a meal in functional dyspepsia. Gastroenterology 1998;115:1346-1352.

83 Sarnelli G, Janssens J, Tack J: Effect of intranasal sumatriptan on gastric tone and sensitivity to distension. Dig Dis Sci 2000;46:15911595.

84 Tack J, Piessevaux H, Coulie B, Fischler B, De Gucht V, Janssens J: A placebo-controlled trial of buspirone, a fundus relaxing drug in functional dyspepsia: effect on symptoms and gastric sensory and motor function (abstract). Gastroenterology 1999;116:A325.

85 Boeckxstaens G, Tytgat G, Wajs E, Van Nueten L, De Ridder F, Tack J: The influence of the $5-\mathrm{HT}_{1 \mathrm{~A}}$ agonist R-137696 on proximal stomach function in healthy volunteers (abstract). Gastroenterology 2004; 126:A437.

86 Tack J, Van Elzen B, Tytgat G, Wajs E, Van Nueten L, De Ridder F, Boeckxstaens G: A placebo-controlled trial of the $5-\mathrm{HT}_{1 \mathrm{~A}}$ agonist R-137696 on symptoms, visceral hypersensitivity and on impaired accommodation in functional dyspepsia (abstract). Gastroenterology 2004; 126:A70.

87 Itoh Z: Motilin and clinical application. Peptides 1997; 18:593-608.

88 Depoortere I, Peeters TL, Vantrappen G: Motilin receptors of the rabbit colon. Peptides 1991;12:89-94.

89 Peeters TL: Erythromycin and other macrolides as prokinetic agents. Gastroenterology 1993; 105:186-199.

90 Coulie B, Tack J, Peeters T, et al: Involvement of two different pathways in the motor effects of erythromycin on gastric antrum in humans. Gut 1998;43:395-400.

91 Chaussade S, Michopoulos S, Sogni P, et al: Motilin agonist erythromycin increases human lower esophageal sphincter pressure by stimulation of cholinergic nerves. Dig Dis Sci 1994 39:381-384.

92 Champion G, Richter JE, Singh S, et al: Effects of oral erythromycin on esophageal $\mathrm{pH}$ and pressure profile in patients with gastroesophageal reflux disease. Dig Dis Sci 1994;39:129137.

93 Janssens J, Peeters TL, Vantrappen G, et al: Improvement of gastric emptying in diabetic gastroparesis by erythromycin. N Engl J Med 1990;322:1028-1031.
94 Richards RD, Davenport K, McCallum RW: The treatment of idiopathic and diabetic gastroparesis with acute intravenous and chronic oral erythromycin. Am J Gastroenterol 1993;88:203-207.

95 Mozwecz H, Pavel D, Pitrak D, et al: Erythromycin stearate as prokinetic agent in postvagotomy gastroparesis. Dig Dis Sci 1990; 7 : 902-905.

96 Camilleri M: The current role of erythromycin in the clinical management of gastric emptying disorders. Am J Gastroentrol 1993;98: 169-171.

97 Magnanti K, Onyemere K, Jones MP: Oral erythromycin and symptomatic relief of gastroparesis: a systematic review. Am J Gastroenterol 2003;98:259-263.

98 Tack J, Peeters T: What comes after macrolides and other motilin stimulants? Gut 2001; 49:317-318.

-99 Arts J, Caenepeel P, Verbeke K, Tack J: Influence of erythromycin on gastric emptying and meal-related symptoms in functional dyspepsia with delayed gastric emptying. Gut 2005; 54:455-460.

100 Bruley des Varannes S, Parys V, Ropert A, et al: Erythromycin enhances fasting and postprandial proximal gastric tone in humans. Gastroenterology 1995; 109:32-39.

101 Cuomo R, Tack J, Vandaele P, Coulie B, Peeters T, Depoortere I, Janssens J: Influence of motilin on gastric fundus tone and on mealinduced satiety in man. Am J Gastroenterol 2006 (in press).

102 Kameling I, Van Haarst A, Burggraaf J, et al: Motilin effects on the proximal stomach in patients with functional dyspepsia and healthy volunteers. Am J Physiol 2003;284: G776-G781.

103 Piessevaux H, Tack J, Wilmer A, et al: Perception of changes in wall tension of the proximal stomach in humans. Gut 2001;49:203208.

104 Minocha A, Katragadda R, Radal PS, Pres A: Erythromycin shortens orocaecal transit time in diabetic male subjects: a double-blind placebo-controlled study. Aliment Pharmacol Ther 1995;9:529-533.

105 Jameson JS, Rogers J, Misiewics JJ, Raimundo AH: Oral or intravenous erythromycin has no effect on human distal colon motility. Aliment Pharmacol Ther 1992;6:589-595.

106 Delvaux M, Louvel D, Fioramonti J, et al: Effect of various doses of erythromycin on colonic myoelectrical activity in IBS patients. Neurogastroenterol Motil 1994;6:205-212.

107 Clark MJ, Wright T, Bertrand PP, et al: Erythromycin derivatives ABT 229 and GM 611 act on motilin receptors in the rabbit duodenum. Clin Exp Pharmacol Physiol 1999; 26:242-245

108 Cowels VE, Nellans HN, Seifert TR, et al: Effect of novel motilide ABT-229 versus erythromycin and cisapride on gastric emptying in dogs. J Pharmacol Exp Ther 2000;293:11061111. 
109 Verhagen MA, Samson M, Maes B, et al: Effects of a new motilide, ABT-229, on gastric emptying and postprandial antroduodenal motility in healthy volunteers. Aliment Pharmacol Ther 1997;11:1077-1086.

110 Talley NJ, Verlinden M, Snape W, et al: Failure of a motilin receptor agonist (ABT-229) to relieve the symptoms of functional dyspepsia in patients with and without delayed gastric emptying: a randomized double-blind placebo-controlled trial. Aliment Pharmacol Ther 2000;14:1653-1661.

$\checkmark 111$ Talley NJ, Verlinden M, Geenen DJ, et al: Effects of a motilin receptor agonist (ABT229) on upper gastrointestinal symptoms in type 1 diabetes mellitus: a randomised, double-blind, placebo-controlled trial. Gut 2001; 49:395-401.

-112 Van Herwaarden MA, Samson M, Van Nipsen $\mathrm{CH}$, et al: The effect of motilin agonist ABT-229 on gastroesophageal reflux, oesophageal motility and lower sphincter characteristics in GERD patients. Aliment Pharmacol Ther 2000; 14:453-462.

$\checkmark 113$ Chen CL, Orr WC, Verlinden KH, et al: Efficacy of motilin receptor agonist (ABT-229) for the treatment of gastro-oesophageal reflux disease. Aliment Pharmacol Ther 2002;16: 749-757.

114 Netzer P, Schmitt B, Inauen W: Effects of ABT-229, a motilin agonist, on acid reflux, oesophageal motility and gastric emptying in patients with gastro-oesophageal reflux disease. Aliment Pharmacol Ther 2002;16: 1481-1490.

115 Eeckhout C: Characterization of KC 11458 as a motilin agonist. Kali-Chemie Pharma GmbH, Report No. K.246.1005, 1995.

116 Brett M, Steibrede H, Schubert CH, Hoofwijk TH: Singe, oral, rising-dose, placebocontrolled, double-blind study of KC 11458 to investigate safety, tolerability and pharmacokinetics in healthy male volunteers. Solvay Pharmaceuticals BV, Clin. Report No. S246.1.102.101, 199.

-117 Russo A, Stevens JE, Giles N, et al: Effect of the motilin agonist KC 11458 on gastric emptying in diabetic gastroparesis. Aliment Pharmacol Ther 2004;20:333-338.

-118 Peeters TL: GM-611 (Chugai Pharmaceutical). Curr Opin Investig Drugs 2001;2:555557.

119 Borovicka J, Kreiss C, Aral K, et al: Role of cholecystokinin as a regulator of solid and liquid gastric emptying in humans. Am J Physiol 1996;271:G448-G453.

120 Wank SA: Cholecystokinin receptors. Am J Physiol 1995;296:G628-G646.

-121 Galligan JJ, Vanner S: Basic and clinical pharmacology of new motility promoting agents. Neurogastroenterol Motil 2005;17: $1-11$.

122 Schwizer W, Borovicka J, Kunz P, et al: Role of cholecystokinin in the regulation of liquid gastric emptying and gastric motility in humans: studies with CCK antagonist loxiglumide. Gut 1997;41:500-504.
123 Feinle C, D’Amato M, Read NW: Cholecystokinin-A receptors modulate gastric sensory and motor responses to gastric distention and duodenal lipid. Gastroenterology 1996;110: 1379-1385.

124 Lal S, McLaughlin J, Barlow J, et al: Cholecystokinin pathways modulate sensations induced by gastric distension in humans. Am J Physiol 2004;287:G72-G79.

125 Feinle C, Meier O, Otto B, et al: Role of duodenal lipid and cholecystokinin A receptors in the pathophysiology of functional dyspepsia. Gut 2001;48:347-355.

126 D'Amato M, Whorwell PJ, Thompson, et al: The efficacy and safety of the CCKA receptor antagonist dexloxiglumide in IBS (abstract). Gut 1999;45(suppl V):A258.

127 Cremonini F, Camilleri M, McKinzie S, et al: Effect of CCK-1 antagonist dexloxiglumide, in female patients with irritable bowel syndrome: a pharmacodynamic and pharmacogenomic study. Am J Gastroenterol 2005; 100:652-663.

128 Wood JD, Galligan JJ: Function of opioids in the enteric nervous system. Neurogastroenterol Motil 2004;16(suppl 2):17-28.

129 Greenwood-Van Meerveld B, Gardner CJ, Little PJ, et al: Preclinical studies of-opioids and-opioid antagonists on gastrointestinal function. Neurogastroenterol Motil 2004; 16(suppl 2):46-53.

130 Camilleri M: Alvimopan, a selective peripherally acting $\mu$-opioid antagonist. Neurogastroenterol Motil 2005; 17:157-165.

131 Zimmerman DM, Gidda JS, Cantrell BE, et al: Discovery of a potent, peripherally selective trans-3,4-dimethyl-4-(3-hydroxyphenyl)piperidin opioid antagonist for the treatment of gastrointestinal motility disorders. J Med Chem 1994;37:2262-2265.

132 Schmidt WK: Alvimopan (ADL 8-2698) is a novel peripheral-opioid antagonist. Am J Surg 2001; 182:S27-S38.

133 Taguchi A, Sharma N, Saleem RM, et al: Selective post-operative inhibition of gastrointestinal-opioid receptors. N Engl J Med 2001; 345:935-941.

134 Wolff BG, Michelassi F, Gerkin T, et al: Alvimopan, a novel peripherally acting $\mu$-opioid antagonist: results of a multicenter, randomized, double-blind, placebo-controlled, phase III trial of major abdominal surgery and postoperative ileus. Ann Surg 2004;240: 728-735.

135 Barr WH, Nguyen P, Slattery M, et al: ADL 8-2698 reverses opiod-induced delay in colonic transit. Clin Pharmacol Ther 2000;67: 91.

136 Garnett W, Kelleher DL, Hickmott F, et al: Alvimopan shortens whole bowel transit time in adults with chronic constipation (abstract). Gastroenterology 2004;126:A643.
137 Tack J, Masclee A, Heading R, et al: A doseranging, placebo-controlled, pilot trial of Z-338 in patients with functional dyspepsia (submitted).

138 Mathias JR, Clench MH, Abell TL, et al: Effect of leuprolide acetate in treatment of abdominal pain and nausea in premenopausal women with functional bowel disease: a double-blind, placebo-controlled, randomized study. Dig Dis Sci 1998;43:1347-1355.

139 Kojima M, Hosoda H, Date Y, et al: Ghrelin is a growth-hormone-releasing acylated peptide from stomach. Nature 1999;402:656660.

140 Depoortere I, De Winter B, Thijs T, et al: Comparison of the gastroprokinetic effects of ghrelin, GHRP-6 and motilin in rats in vivo and in vitro. Eur J Pharmacol 2005;515:160 168.

141 De Winter BY, De Man JG, Seerden TC, et al: Effect of ghrelin and growth hormone-releasing peptide 6 on septic ileus in mice. Neurogastroenterol Motil 2004;16:439-446.

142 Tack J, Depoortere I, Bisschops R, et al: Influence of ghrelin on interdigestive gastrointestinal motility in man. Gut 2005. Oct 10 [Epub ahead of print].

143 Tack J, Depoortere I, Bisschops R, et al: Influence of ghrelin on gastric emptying and mealrelated symptoms in idiopathic gastroparesis. Aliment Pharmacol Ther 2005;22:847853.

144 Azpiroz F, Malagelada JR: Vagally mediated gastric relaxation induced by intestinal nutrients in the dog. Am J Physiol 1986;251: G727-G735.

145 Sanders KM, Ward SM: Nitric oxide as a mediator of nonadrenergic noncholinergic neurotransmission. Am J Physiol 1992;262:379_ 392.

146 Kelly J, MacDonald A: Relaxant effect of $\alpha$ adrenoceptor agonist in the rat isolated gastric fundus. J Pharm Pharmacol 1990;42: 30-34.

147 Gilja OH, Hausken T, Bang CJ, Berstad A: Effect of glyceryl trinitrate on gastric accommodation and symptoms in functional dyspepsia. Dig Dis Sci 1997;42:2124-2131.

148 Sarnelli G, Sifrim D, Janssens J, Tack J: Influence of sildenafil on gastric sensorimotor function in man. Am J Physiol 2004;287: G988-G992.

149 Thumshirn M, Camilleri M, Choi MG, Zinsmeister AR: Modulation of gastric sensory and motor functions by nitrergic and $\alpha_{2}$-adrenergic agents in humans. Gastroenterology 1999; 116:573-585.

150 Tack J, Caenepeel P, Corsetti M, Janssens J: Role of tension receptors in dyspeptic patients with hypersensitivity to gastric distention. Gastroenterology 2004;127:1058-1066.

151 Asai T, McBeth C, Stewart JL, et al: Effect of clonidine on gastric emptying of liquids. $\mathrm{Br} \mathrm{J}$ Anaesth 1997; 78:28-33.

$>152$ Rosa-E-Silva L, Troncon LEA, Oliveira RB, et al: Treatment of diabetic gastroparesis with oral clonidine. Aliment Pharmacol Ther 1995;9:179-183. 